\title{
Applying constructional approach to second language teaching and learning
}

\author{
Svetlana Viktorovna Ivanova $^{1}$ and Svetlana Nikolaevna Medvedeva ${ }^{2 *}$ \\ ${ }^{1}$ Pushkin Leningrad State University, Department of Romance and Germanic Philology and \\ Linguodidactics, Saint-Petersburg, Russia \\ ${ }^{2}$ Saint-Petersburg State University of Economics, Department of Theory and Practice of the English \\ Language and Translation, Saint-Petersburg, Russia
}

\begin{abstract}
The inevitability of addressing constructional approach in modern linguodidactics is caused by the crisis in teaching practices aimed at providing students with a set of static information. The ever- and fast-changing nature of the modern system of knowledge leads to the necessity of teaching students how to search for, analyze and critically assess actual language data. The paper discusses problems and prospects of applying constructional approach in second language teaching and learning and posits an algorithm of studying construction semantics of the "noun + get + adjective' construction as an example. The research methods include analysis and synthesis for identifying problems and prospects of introducing constructional approach in second language learning. A set of resultative meanings of the 'noun + get + adjective' construction is obtained by way of semantic clusterisation. As a result, major advantages and challenges of applying constructional approach to second language teaching and learning are established. The paper emphasizes the need for students to have a sufficient theoretical basis in language typology and corpus linguistics. The current research also offers an algorithm of construction analysis and includes a listing of key resultative meanings of the 'noun + get + adjective' construction and its restrictions. The results can be of certain interest for corpus linguistics and construction semantics. Prospects for the future research in this field reside in developing strategies aimed at introducing construction grammar in the learning process and cataloguing constructions within different types of languages as well as identifying dependencies between constructional patterns and types of languages.
\end{abstract}

Keywords: construction semantics, corpus linguistics, second language learning, construction grammar

\section{Introduction}

Modern linguodidactics is experiencing a critical moment as it has to reassess the existing teaching practices in the search for new techniques and approaches which would facilitate

\footnotetext{
*Corresponding author: medvedeva.s@unecon.ru
} 
in-class performance. Besides these global factors affecting the teaching and learning process, there are some intralinguistic aspects of the problem that are connected with certain approaches to language description. The first to mention is lexicographic practices. As is known, dictionary compilers never aim at covering all words or a whole range of their contextual meanings. Hence, dictionaries cease being the only lexicographic source to depend on in second language teaching and learning (SLT\&L).

The traditional teaching method with 'a strict division between the lexicon as a repository of meaningful words and morphemes and meaningless syntactic rules' sometimes has nothing to do with communicative skills [1]. No wonder, due to the 'unpredictability of meaning' [2] such expressions as 'How do you do?' are included in dictionaries as separate language entries. According to M. Bila and A. Kacmarova, the meaning of such multi-word units 'is not generated again and again, rather stored in the users' minds' [3].

Conventionalised expressions constitute the most typical operational units of language, i.e. constructions. B. Leclercq also states that 'when discussing the meaning of constructions, one already focuses on meaning conventions' [4]. Moreover, the notion of construction 'encompasses morphemes, words, idioms, as well as abstract phrasal patterns' [5].

These assumptions emphasize the need to modernise teaching practices in linguodidactics embracing the achievements of construction grammar and incorporating the constructional corpus-based approach within language studies.

\section{Methods}

The current paper belongs to a series of research studies on semantic variability of 'verb + nominal part of speech' constructions in English. The objective of the work is to display the application of constructional approach to solving SLT\&L problems using the analysis of semantic variability of the 'noun + get + adjective' construction as an example. The verb 'get' belongs to one of the most frequent and semantically diverse verbs in the modern English language which is often analysed in recent studies from historical [6]; second language learning [7-9]; semantic [10-12]; constructional and corpus-based [13, 14]; bilingual translations $[15,16]$ perspectives.

The research encompasses a consecutive implementation of the following procedures:

1. Defining prospects and issues of applying constructional approach in SLT\&L.

2. Forming a request in corpus database and creating a representative sampling of the 'noun + get + adjective' construction instances, or collostructions.

3. Contextual analysis of the obtained collostructions in order to increase the quality of the sampling.

4. Semantic clusterisation of the right- and left-context collocates of the verb 'get'.

5. Interpretation of the resultative meanings of the clusters.

After discussing the application of constructional approach to SLT\&L, the article presents an algorithm of constructional analysis and identification of the semantic variability of the verb in the construction under study.

The research employs analysis and synthesis for positing advantages, downsides and prospects of applying constructional approach in SLT\&L. The empirical part of the research draws upon Corpus of Contemporary American (COCA).

First, the request NOUN GET ADJ formed in COCA. The request and contextual analysis resulted in 4047 collostructions - the instances of the construction under study. 
The initial sampling is formed by the continuous sampling method. After the refinement of the sampling, the obtained collostructions are divided into groups by the semantic clusterisation method. It implies that variable right- and left-context elements in collostructions possess mutual hypo-hyperonymous links (e.g. 'women: mother/ girl/ wife get pregnant') which can serve as evidence of a viral nature of the collocation. Consequently, resultative meaning of each of the clusters is defined.

\section{$3 \quad$ Results}

One of the prospects of constructional approach is large sets of unexplored language data which can motivate teachers and students to not only study a foreign language or translation but also develop a wide range of soft skills - to learn in practice how to search for information, to critically assess it, to analyse it, to make well-thought conclusions and give proper arguments when interpreting language facts. Furthermore, the language data from corpora are available for qualitative and quantitative processing and interpretation. In other words, 'corpora may provide counterexamples for hitherto widely-accepted claims' [17].

From a communicative standpoint, constructional approach may prove efficient in overcoming language interference, and help increase fluency and develop skills of spontaneous speech [18]. According to M. Fried, 'knowing a language with a native-like fluency means knowing (and learning) the constructions of that language' [19].

Nevertheless, introduction of constructional approach in SLT\&L, despite being extremely timely, faces some challenges:

1. Students' lack of theoretical knowledge. Studying constructions, students are assumed to have certain knowledge and skills to work with language corpora and concordances which highlights the need for preliminary theoretical preparation.

2. Relevance. At the moment comprehensive corpora have been developed only for major languages (e.g. English, German, Russian, etc.). The volume, balance, scope, time period and relevance of the data constitute a different issue which can affect the quality of samplings and distort the results. Additionally, tagging also makes work with the data complicated.

3. Speed and efficiency. According to I.N. Remkhe and L.A. Nefyodova, "translators find it time-consuming and unreliable at times of tight schedules' [20].

3. In its turn, introduction of constructional approach requires experimental substantiation of its efficiency and a thorough restructuring of teaching practices which can be a complicated and time-consuming enterprise [21]. To resolve the restrictions of applying constructional approach to SLT\&L, construction semantics and patters must be studied further to obtain a critical mass of data.

Henceforth the 'noun + get + adjective' construction will be discussed in detail. The collostructions of the 'noun + get + adjective' construction form six clusters (Table 1).

Table 1. Clusters of collostructions of the 'noun+ get + adjective'.

\begin{tabular}{|c|l|l|l|l|l|}
\hline No. & \multicolumn{1}{|c|}{$\begin{array}{c}\text { Left } \\
\text { context }\end{array}$} & VERB & \multicolumn{1}{c|}{$\begin{array}{c}\text { Right } \\
\text { context }\end{array}$} & $\begin{array}{c}\text { Resultative } \\
\text { meaning }\end{array}$ & \multicolumn{1}{c|}{ Notes } \\
\hline 1 & $\begin{array}{l}\text { thing(s), } \\
\text { situation, } \\
\text { problem, } \\
\text { going(s) }\end{array}$ & GET & $\begin{array}{l}\text { bad, worse, } \\
\text { serious, } \\
\text { complicated, } \\
\text { difficult, } \\
\text { heated, } \\
\text { hot, crazy, } \\
\text { weird, messy, }\end{array}$ & $\begin{array}{l}\text { worsening of } \\
\text { the situation }\end{array}$ & $\begin{array}{l}\text { The largest cluster }-1484 \\
\text { instances }(\sim 36,7 \%) . \\
\text { Right-context collocates share } \\
\text { the semi 'danger' or } \\
\text { 'complication'. A significant } \\
\text { number of collocates consists of } \\
\text { root + y suffix. Adjectives based }\end{array}$ \\
\hline
\end{tabular}




\begin{tabular}{|c|c|c|c|c|c|}
\hline & & & $\begin{array}{l}\text { rough, tough, } \\
\text { ugly, hairy, } \\
\text { dicey, sticky, } \\
\text { tricky }\end{array}$ & & $\begin{array}{l}\text { on this morphological model } \\
\text { typically mean uncontrollable } \\
\text { and weird state (e.g. 'barmy', } \\
\text { 'loopy', and 'dicey', 'hairy', } \\
\text { 'messy'). }\end{array}$ \\
\hline 2 & things & GET & $\begin{array}{l}\text { better, } \\
\text { interesting }\end{array}$ & $\begin{array}{l}\text { improvement } \\
\text { of the } \\
\text { situation }\end{array}$ & $\begin{array}{l}\text { Comparatively small frequency } \\
\text { and variety of collocates. }\end{array}$ \\
\hline 3 & $\begin{array}{l}\text { days, } \\
\text { weather }\end{array}$ & GET & $\begin{array}{l}\text { shorter, } \\
\text { colder, } \\
\text { warmer }\end{array}$ & $\begin{array}{l}\text { change of } \\
\text { weather }\end{array}$ & $\begin{array}{l}\text { The collostructions are strongly } \\
\text { connected to high-frequency } \\
\text { attributive collostuctions, e.g. } \\
\text { 'the weather gets colder - cold } \\
\text { weather'. }\end{array}$ \\
\hline 4 & $\begin{array}{l}\text { things, } \\
\text { message, } \\
\text { invitation }\end{array}$ & GET & lost & $\begin{array}{l}\text { loss of } \\
\text { objects }\end{array}$ & $\begin{array}{l}\text { Collostructions } \\
\text { elements with antonymous } \\
\text { semantics, i.e. 'get' - 'to receive, } \\
\text { to obtain', while 'lost' is } \\
\text { Participle II from the verb 'lose' } \\
\text { which means' to no longer have } \\
\text { something because you do } \\
\text { not know where it is'. }\end{array}$ \\
\hline 5 & $\begin{array}{l}\text { face, } \\
\text { eyes, } \\
\text { knees, } \\
\text { feet }\end{array}$ & GET & $\begin{array}{l}\text { red, hot, big, } \\
\text { wide, weak, } \\
\text { cold }\end{array}$ & $\begin{array}{l}\text { physiological } \\
\text { reactions as a } \\
\text { consequence } \\
\text { of emotions }\end{array}$ & $\begin{array}{l}\text { The left-context collocates define } \\
\text { parts of the body. Strong } \\
\text { connections to high-frequency } \\
\text { attributive collostuctions - 'red } \\
\text { face', 'wide eyes', 'weak knees', } \\
\text { 'cold feet'. }\end{array}$ \\
\hline 6 & [people] & GET & $\begin{array}{l}\text { [status or a } \\
\text { state] }\end{array}$ & $\begin{array}{l}\text { change of } \\
\text { emotional or } \\
\text { physiological } \\
\text { state of } \\
\text { people, their } \\
\text { state or status }\end{array}$ & $\begin{array}{l}\text { The left-context collocates define } \\
\text { groups of people. }\end{array}$ \\
\hline 6.1 & $\begin{array}{l}\text { women, } \\
\text { girls, wife, } \\
\text { mother }\end{array}$ & GET & pregnant & $\begin{array}{l}\text { conceiving a } \\
\text { baby }\end{array}$ & $\begin{array}{l}\text { The right-context collocate } \\
\text { restricts left-context collocates } \\
\text { (female humans). }\end{array}$ \\
\hline 6.2 & $\begin{array}{l}\text { parents, } \\
\text { people }\end{array}$ & GET & divorced & $\begin{array}{ll}\text { breaking } & \text { a } \\
\text { marriage } & \\
\end{array}$ & \\
\hline 6.3 & people & GET & $\begin{array}{l}\text { mad, angry, } \\
\text { fed up, stuck, } \\
\text { confused, } \\
\text { tired, scared, } \\
\text { upset, } \\
\text { frustrated, } \\
\text { nervous, } \\
\text { desperate, } \\
\text { bored, sick }\end{array}$ & $\begin{array}{l}\text { a negative } \\
\text { change of } \\
\text { mood }\end{array}$ & $\begin{array}{l}\text { The right-context collocates } \\
\text { define strong emotions of fear, } \\
\text { annoyance or anger. }\end{array}$ \\
\hline 6.4 & $\begin{array}{l}\text { people, } \\
\text { person, } \\
\text { mother, } \\
\text { father, } \\
\text { child(ren), } \\
\text { kid, wife } \\
\end{array}$ & GET & sick & falling ill & $\begin{array}{l}\text { The left-context collocates } \\
\text { contain hyperonyms (people, } \\
\text { person) and hyponyms which } \\
\text { share the seme 'family'. }\end{array}$ \\
\hline 6.5 & people & GET & rich & $\begin{array}{l}\text { financial } \\
\text { welfare }\end{array}$ & \\
\hline
\end{tabular}




\begin{tabular}{|c|l|l|l|l|l|}
\hline 6.6 & $\begin{array}{l}\text { people, } \\
\text { men, } \\
\text { women }\end{array}$ & GET & old & become old & \\
\hline 6.7 & $\begin{array}{l}\text { child(ren), } \\
\text { kids, } \\
\text { students }\end{array}$ & GET & older & grow up, age & $\begin{array}{l}\text { Despite the fact that the } \\
\text { right-context collocates 'old' and } \\
\text { 'older' represent a positive and a } \\
\text { comparative forms of the same } \\
\text { adjective, th left-context } \\
\text { collocates in clusters 6.6 and 6.7 } \\
\text { do not interchange, i.e. 'kids get } \\
\text { older', but not *'kids get old'. } \\
\text { These limitations can be } \\
\text { connected to a kind of } \\
\text { universally shared prototypical } \\
\text { assumptions. }\end{array}$ \\
\hline 6.8 & $\begin{array}{l}\text { people, } \\
\text { kid }\end{array}$ & GET & $\begin{array}{l}\text { hurt, } \\
\text { killed }\end{array}$ & to be injured & \\
\hline
\end{tabular}

\section{Discussion}

Speaking of resultative meanings of constructions, it is worth mentioning that the verb 'get' in the construction is desemantisized and functions as an auxiliary verb in a complex nominal predicate. Complex predicates constitute a large proportion of predicative structures in English, which is related to its typological features. The English language is a language with predominant analytical tendencies. These tendencies imply that typically the language has analytical forms of predicates consisting of an auxiliary verb and a nominal or verbal component. The auxiliary verb is generally desemantisized and has a grammatical meaning while the nominal or verbal component is grammatically static and expresses the semantics of the complex predicate. Such allocation of responsibilities explains why, despite the semantics of the verb 'get' ('to receive, to obtain'), collostructions 'get small', 'get short', 'get lost' do not contain any internal contradictions in their semantics. The verb 'get' here is desemantisized and only performs in a linking function. Moreover, is can be assumed that certain language types gravitate towards specific constructional patterns.

\section{Conclusion}

As a result of the current research, the major advantages and issues related to the application of constructional approach in SLT\&L are identified. The need for students' substantial theoretical awareness is highlighted. The major resultative meanings and their restrictions of 'noun + get + adjective' clusters have been detected. The results obtained can be further used as a case study in corpus linguistics, semantics or theoretical grammar. The prospects of studying construction semantics are connected with cataloguing constructional patterns in languages belonging to different types and ascertaining pattern regularities and dependencies. To sum up, to be seamlessly introduced in SLT\&L constructional approach in linguodidactics requires revising teaching practices and techniques which should undergo cardinal changes.

\section{References}


1. T. Hoffmann, Construction grammars, in B. Dancygier (ed), The Cambridge Handbook of Cognitive Linguistics, 310-329 (Cambridge University Press, Cambridge, 2017). https://doi.org/10.1017/9781316339732.020

2. M. Hladnik, Engl Lang Overseas Persp Enquir, 14(2), 25-37 (2017). https://doi.org/10.4312/elope.14.2.25-37

3. M. Bila, A. Kacmarova, Rus J Ling, Bul RUDN, 20, 164-175 (2016)

4. B. Leclercq, Belg J Ling, 34, 228-238 (2021). https://doi.org/10.1075/bj1.00048.lec

5. T. Hoffmann, Belg J Ling, 34, 149-161 (2020). https://doi.org/10.1075/bj1.00042.hof

6. V. Shabaev, Sib J Life Sci Agricult, 1.1, 875-887 (2015). https://doi.org/10.12731/wsd-2015-1.1-36

7. Z.H. Almad, Difficulties Faced by Iraqi EFL University Students in Using the Verb "GET" (2018). Accessed on: October 19, 2021. [Online]. Available: https://www.researchgate.net/publication/326092741_Difficulties_Faced_by_Iraqi_EF L_University_Students_in_Using_the_Verb_GET/references

8. J.A. Malone, The L2 acquisition of the English verb get by native speakers of Spanish, M.A. Thesis (Southern Illinois University, Carbondale, 2004)

9. L. Sánchez, From L2 to L3, verbs getting into place: A study on interlanguage transfer and L2 syntactic proficiency, in Third Language Acquisition. Age, Proficiency and Multilingualism (Language Science Press, 2021)

10. E. Chon, Y.-K. Joh, English 21, 31(2), 233-251 (2018).

https://doi.org/10.35771/engdoi.2018.31.2.010

11. G. Rafibeyli, Sci Work, 11/60, 31-37 (2020). https://doi.org/10.36719/2663-4619/60/31-37

12. L.T. Crowell, A study of the verb "get" (Columbia university, 1955)

13. A. Özbay, Novitas-ROYAL, 14(2), 38-57 (2020)

14. L. González-Romero, Phil Canariensia, 65-94 (2021). https://doi.org/10.20420/Phil.Can.2021.376

15. M. Mogahed, Arab World Engl J, 6, 242-264 (2015). https://doi.org/10.24093/awej/vol6no2.18

16. E.H. Rodríguez, J Sci, 2 (2018). https://doi.org/10.15406/oajs.2018.02.00098

17. S.Th. Gries, Data in Construction Grammar, in T. Hoffmann, G. Trousdale (eds), The Oxford Handbook of Construction Grammar (2021). https://doi.org/10.1093/oxfordhb/9780195396683.013.0006

18. S. Medvedeva, Constructional approach in teaching foreign languages and translation, in M.V. Norets (ed), Translation Discourse: Interdisciplinary Approach, 193-199, April 29-30 (Publishing House Printing House "Arial”, Simferopol, 2021)

19. M. Fried, Construction Grammar, in A. Alexiadou, T. Kiss (eds), Syntax - Theory and Analysis. An International Handbook (Mouton de Gruyter, 2015). https://doi.org/10.13140/RG.2.1.1860.7447

20. I. Remkhe, L. Nefyodova, Iss Cogn Ling, 2(43), 89-95 (2015)

21. S. Medvedeva, Serv Plus, 15(2), 115-123 (2021) 